\title{
Entre barba e purpurina: Pedagogias e Dramaturgias ao estilo Dzi Croquettes
}

\author{
Between beard and glitter: \\ Pedagogies and Dramaturgies in Dzi Croquettes style
}

Gustavo de Oliveira Duarte ${ }^{1}$

Odailso Sinvaldo Berté 2 


\section{Resumo}

O presente estudo objetiva refletir sobre elementos da vida e obra do grupo Dzi Croquettes para lançar questionamentos ao ensino universitário de dança na contemporaneidade. Esta reflexão é organizada a partir da análise de imagens do filme Dzi Croquettes, que documenta parte da trajetória do referido grupo, em consonância com o conceito de performatividade. Com isso busca-se questionar relações de saber e poder no ensino de dança e nas relações entre corpo e pedagogia para articular formas alternativas de fazer-pensar processos e dramaturgias de dança.

Palavras chave: Dança; dramaturgia; pedagogia; performatividade; Dzi Croquettes

\section{Abstract}

The current study aims to reflect on elements of the life and work of the Dzi Croquettes group to launch questions about dance teaching at the university in the contemporary world. This reflection is organized from the image analysis of the Dzi Croquettes movie, which documents part of the trajectory of this group, in consonance with the concept of performativity. Thereby, the aim of the study is to question relations of knowledge and power in dance teaching and in the relationships between body and pedagogy to articulate alternative ways of doing-thinking processes and dance dramaturgies.

Keywords: Dance; dramaturgy; pedagogy; performativity; Dzi Croquettes 


\section{Corpos entre fronteiras}

Dentre as motivações que movem nossos afetos no estudo e escrita deste texto estão as instigantes imagens do filme documentário Dzi Croquettes (BRA, 2010), dirigido por Tatiana Issa e Raphael Alvarez. Esse filme descreve partes da trajetória do grupo brasileiro de dança e teatro Dzi Croquettes, compreendida entre 1972 e 1976. "Uma das experiências mais revolucionárias das artes performáticas nos séculos XX e XXI" (Müller, 2010, p. 13) realizada por "corpos masculinos" com "barbas e purpurina" é como Müller (2010) descreve essa sagaz experiência artística instaurada durante o árduo período de repressão política e cultural, censura, violência e mortes do regime militar em nosso país.

Fenômeno da contracultura, manifestação vanguardista de teatro, precursores do movimento gay organizado, grupo de malucos e jovens irreverentes, subversivos ou pornográficos, "bando de viados" e degenerados da sociedade, tudo isso - e muito mais - caberia no cenário político dos anos da ditadura militar no Brasil e dos movimentos libertários do contexto internacional da época. (Müller, 2010, p. 13)

Além de compilar um importante registro de imagens dos espetáculos e de depoimentos dos artistas do Dzi Croquettes, o filme reúne ex-integrantes, admiradores e personalidades nacionais e internacionais do cinema, da televisão, da música, da dança e do teatro que relatam suas experiências de convívio e trabalho com o grupo. Com espetáculos apresentados inicialmente em pequenos palcos de casas noturnas (boates) e depois em palcos de teatro, o grupo Dzi Croquettes mostrou diferentes trabalhos nas cidades brasileiras do Rio de Janeiro e São Paulo e ainda nas cidades europeias de Lisboa, Paris, Turim e Milão.

Ao olhar para as imagens do filme Dzi Croquettes e para elementos da trajetória do referido grupo, interessa-nos refletir sobre os modos como esses corpos borravam fronteiras artísticas, políticas e de gênero. Instiga-nos pensar sobre as propostas artísticas contestadoras criadas por esses corpos que, com purpurina, flores e paetês, provocaram o regime militar promulgando imagens andróginas de afronta ao modelo vigente de masculinidade e heteronormatividade. Nesse sentido, olhar para a experiência artística do grupo Dzi Croquettes, compreendida na década de setenta, é um modo de buscar referências na história da dança do Brasil para refletir e propor modos de fazer-pensar, processos (de ensino e criação) e dramaturgias na dança que valorizem a diversidade e estimulem posicionamentos críticos, criativos e performativos de diferentes corpos.

Motivados por isso nos perguntamos sobre o ensino universitário de dança hoje: a que nos levam as danças que, como professores, ensinamos ou incentivamos aos alunos criarem? Quais propostas movem e sustentam esses processos criativos e pedagógicos? Quais proposições, imagens, questionamentos as danças contemporâneas estão causando? Com essas perguntas não defendemos que a dança deva transmitir mensagens prontas, siglas partidárias, causas panfletárias ou ainda ser apenas um instrumento 'de' e 'para'. Trata-se de pensarmos sobre o não tratamento da dança como alegoria de enfeite ou válvula de escape, externa e alheia à vida dos corpos e contextos que lhes dão vida. Se quem dá vida à dança são corpos, essa dança não pode ser acéfala, alheia ao que lhe dá vida. O contexto/ambiente sócio-político-cultural em quem vivemos hoje, no Brasil e no 
mundo, exige que reflitamos acerca de que necessidade tem de fazer dança, que dança estamos produzindo e que sentidos ela tem e possibilita aos corpos.

\section{Dzi Croquettes e o movimento homossexual brasileiro}

Conforme relata o ator Pedro Cardozo, em depoimento no filme em questão, o espetáculo do Dzi Croquettes "não era um espetáculo gay. Havia uma sexualidade boa, masculina, feminina, homossexual. Havia uma possibilidade absoluta do exercício da sexualidade" (Dzi Croquettes, 2009). Embora não fosse um trabalho artístico vendido sob o rótulo gay, é possível ver nas imagens que remetem às montagens cênicas do $D z i$ Croquettes o quanto sua obra era permeada pelo borramento de fronteiras de gênero, sexualidade, comportamento, de expressão e de arte. O escracho, a ironia e o rompimento de padrões eram princípios dramatúrgicos que selecionavam e organizavam o que estava em cena. Essa irreverência vinha do cotidiano dos componentes do Dzi, permeava o espetáculo e difundia-se entre os seus seguidores e seguidoras chamados de "os/as tietes". Estes passaram a se comportar, se vestir e se relacionar como eles. A proposta artística dos Dzi potencializou que diferentes sujeitos homossexuais pudessem se expressar, entenderem-se como cidadãos vivendo em sociedade.

A arte do grupo Dzi Croquettes pode ser relacionada à construção do movimento gay no Brasil. É importante considerar as mudanças, complexas, que ocorreram na organização social da homossexualidade no final do século XX, considerando-as, portanto, homossexualidades, como já problematizado por João Silvério Trevisan em "ser ou não ser brasileiro" e "ser ou não ser homossexual" (Trevisan, 2004). A diversidade e a complexidade da cultura brasileira podem apontar para diferentes significados, em diferentes regiões, como a Norte e a Nordeste, a Sudeste e a Sul, onde as

[...] questões comportamentais relacionadas com HIV/Aids eram de fato moldadas por mudanças que ocorriam na organização das redes sexuais e de amizade, universos subculturais e comunidades sexuais. (Parker, 2002, p.41)

Este conjunto de múltiplas realidades nos leva a considerar uma variedade de expressões homossexuais distintas e contingenciais em vez de "explicá-la" como "a" homossexualidade, única e, portanto, fixa.

Em relação à trajetória do movimento homossexual brasileiro destacamos a análise realizada por Julio Simões e Regina Facchini a partir do final dos anos de 1970 com o surgimento de grupos voltados explicitamente à militância política. A constituição do grupo Somos, de São Paulo, em 1978, e o lançamento do jornal Lampião da Esquina, foram fundamentais para a compreensão dos processos de politização da homossexualidade que ocorreram no Brasil. Julio e Regina organizaram a trajetória do movimento segundo periodizações relacionadas a diferentes fases, nomeadas de "ondas", de acordo com as mudanças sociais e políticas que moldaram suas formas de atuação.

A primeira onda compreende o final do regime militar, o período de abertura política, de 1978 em diante; a segunda onda ilustra o período de redemocratização acerca da Assembleia Constituinte e o aparecimento da epidemia do HIV-Aids; final- 
mente, a terceira onda, a partir dos anos 1990, que consolida a parceria com o Estado e a multiplicação de grupos ativistas promovendo a diversificação de vários sujeitos a partir da atual designação LGBTT (lésbicas, gays, bissexuais, transgêneros e transexuais). Este período também assinala a expansão de um mercado segmentado voltado à homossexualidade: moda e design, festas, diversão, lazer, viagens, entre outros.

A partir do surgimento da Aids no início da década de 1980 e a associação direta com as práticas de gays, lésbicas e bissexuais, intensificaram-se os processos de mobilização social e política que já vinham ocorrendo no movimento gay, no sentido da defesa da causa da Aids, os quais acabaram por contribuir e fortalecer uma visão mais ampla e, de certa forma, "responsável" da homossexualidade. A formação de inúmeras ONGs/Aids e o interesse na prevenção buscou atingir não somente a chamadas "populações de risco", na época, mas também, homens e mulheres heterossexuais. A ideia de uma identidade homossexual é crescente e torna-se fundamental dentro da noção de comunidade gay, urbana e de classe média.

Dos integrantes do grupo Dzi Croquettes, Lennie Dale, Cláudio Gaya, Eloy Simões e Paulo Bacellar morreram de Aids. Pertencentes ao momento histórico em que pouco se sabia sobre as causas e os tratamentos mais adequados para esta deficiência imunológica, eles também foram considerados como vítimas do "câncer gay". Embora eles não tenham levantado, explicitamente, bandeiras de movimentos sociais organizados, diferentes elementos e fatos possibilitam aproximações e (co) incidências entre a vida e a obra do grupo Dzi Croquettes e a visibilidade do movimento homossexual brasileiro.

Dançarinos, multifacetados, seus espetáculos questionavam os valores de uma época e contribuíram na produção espaços de resistência, de colaboração, de compartilhamento, de aprendizado, de invenção e outras formas do (sobre)viver. O grupo acabou inventando outros modos de ser e de se relacionar no Brasil de outrora. Homens travestidos, mas que não se identificavam como travestis. A partir da compreensão da cultura em que vivemos como heterossexista, Fernando Pocahy (2011) aponta algumas possibilidades de resistência em relação aos discursos hetero e homonormativos, que se aproxima de uma "vida criativa", inspirada nas teorizações de Michel Foucault.

Compartilhamos de sua posição quando o autor destaca que é possível a "[...] a construção de 'outro horizonte discursivo', acompanhando movimentos que nos permitem viver/pensar a sexualidade do ponto de vista de uma erótica, não de uma 'ciência sexual'" (Pocahy, 2011, p.48).

O aumento da visibilidade tanto social quanto política veio fortalecer

[...] a formação da cena gay nas grandes cidades brasileiras, refletindo a crescente importância do mercado e difusão de imagens, estilos corporais, hábitos e atitudes associadas às variadas expressões das homossexualidades. (Simões e Facchini, 2009, p.18)

Por outro lado, a violência das mais diversas ordens como xingamentos, humilhações e até mesmo agressões físicas, absurdas e covardes, continuaram e ainda fazem parte do cotidiano de muitos homossexuais brasileiros, sobretudo os que se mostram mais afeminados e/ou delicados e, principalmente, as travestis. No entanto, podemos 
dizer que as conquistas do movimento homossexual permitiram às novas e atuais gerações certas vantagens e ganhos significativos antes impensáveis às gerações mais antigas.

Atualmente, a questão da cidadania LGBTT e da luta por direitos, das mais variadas ordens, está disseminada em jornais e revistas, em novelas de televisão, nas organizações não-governamentais, em causas trabalhistas, em projetos de Escolas, em tribunais e audiências jurídicas e, sobretudo, na expressão cada vez mais "precoce" da juventude gay atualmente.

\begin{abstract}
A vida da maior parte dos que hoje se consideram gays, lésbicas, bissexuais, travestis e transexuais no Brasil é, sem dúvida, muito menos complicada e sofrida do que a dos que vieram antes. Faz uma enorme diferença poder desfrutar de uma existência razoavelmente respeitável "fora do armário", em que as tensões impostas pela clandestinidade e a vergonha, embora ainda presentes, estão bem mais atenuadas em comparação com outras épocas e situações. E se essa é uma experiência real para as atuais gerações, assim como um projeto de vida plausível para as gerações futuras, e não apenas de uns poucos privilegiados, é devido, em grande parte, ao ativismo contra o preconceito e em defesa da cidadania LGBT. (Simões e Facchini, 2009, p. 28)
\end{abstract}

Conforme relata o diretor de teatro José Possi Neto, no filme Dzi Croquettes, esses artistas "não estavam" explicitamente "engajados com política institucional", no entanto "é claro que era político, qualquer ato é político". Havia uma espécie de "revolução de comportamento, de liberação sexual, de valores morais com relação à masculinidade e feminilidade" (Dzi Croquettes, 2009). A força político-estética do trabalho dos Dzi alavancou, de certa forma, variadas formas de expressão e visibilidade das identidades homossexuais. Parte da liberdade de expressão hoje conquistada vem dessas e outras formas de manifestação que encamparam as articulações políticas e identitárias afloradas em meio às tensões políticas vividas naquela época.

\title{
"Profissional" e "albarde": elementos performativos na dança dos Dzi
}

Berté (2015), em referência a Butler (2012), usa o filme Paris is Burning (USA, 1990), de Jennie Livingston, e o videoclipe Vogue (USA, 1990), da cantora norte-americana Madonna, para refletir sobre as práticas anticonvencionais e ressignificadoras de drag queens e dançarinos de vogue da ball culture - ambiente underground dos clubes gays de New York, década de 1980 . Os modos como Berté $(2015$, p. 169) reflete, com essas imagens, sobre as práticas performativas daqueles corpos queer, propondo o que chama de "dança contempop", nos impelem a pensar, com as imagens do filme Dzi Croquettes, acerca das experiências artísticas desse grupo no intuito de também propor espaços e posicionamentos críticos, criativos e performativos no ensino contemporâneo de dança.

O grupo Dzi Croquettes era formado por atores, dançarinos, pintores, músicos que começaram a levar "uma vida underground no sentido mais profundo" (Lobert, 2010, p. 22). Eles criavam vestuários transgressores que, ao serem trajados por eles em cena, instauravam imagens que confrontavam os padrões sociais machistas. A arte desse grupo surge como pequenas apresentações realizadas em boates cariocas e paulistas, nos intervalos dos shows principais. Trata-se de um ambiente underground 
formador que concedeu aos seus trabalhos marcas peculiares, as quais não foram apagadas quando o grupo alçou voo para os palcos dos teatros consagrados como espaços destinados à arte. Essas experiências acumuladas não foram descartadas perante o crescimento profissional e técnico do trabalho artístico. Conforme Lobert (2010, p. 134), o clima da "boate era conservado [...], o estilo descontraído, o clima cálido e a proximidade com os espectadores", o gracejo, a irreverência, a informalidade calculada são elementos que conferiram a marca central do espetáculo do Dzi Croquettes.

Conforme destaca Lobert (2010) esse "grupo de homens suspeitosamente travestidos" irrompe dos palcos estreitos de boates aos largos palcos dos teatros - "espaço economicamente reservado a classes burguesas com preocupações intelectuais" (Lobert, 2010, p. 28). Quando, em 1973, os Dzi Croquettes tiveram seu show transferido da Boate Ton-Ton para o Teatro Treze de Maio, em São Paulo, este foi classificado pela imprensa como um show de travestis. Para o público eles eram andróginos, um modo de classificação mais aceitável de acordo com a proposta artística que eles apresentavam.

A entrada do dançarino, coreógrafo, cantor e compositor norte-americano Lennie Dale no grupo, trouxe os elementos técnicos e profissionais da dança que, entrecruzados com a caraterística albarde, foram ampliando a proposta estética do Dzi Croquettes. Lennie Dale, figura de destaque na televisão brasileira e em shows de boates, protagonizava o show principal, no intervalo do qual, se apresentavam os Dzi Croquettes. Em dado momento, eles resolvem misturar seus números artísticos, conectando elementos de dança moderna e jazz com o estilo albarde ${ }^{3}$.

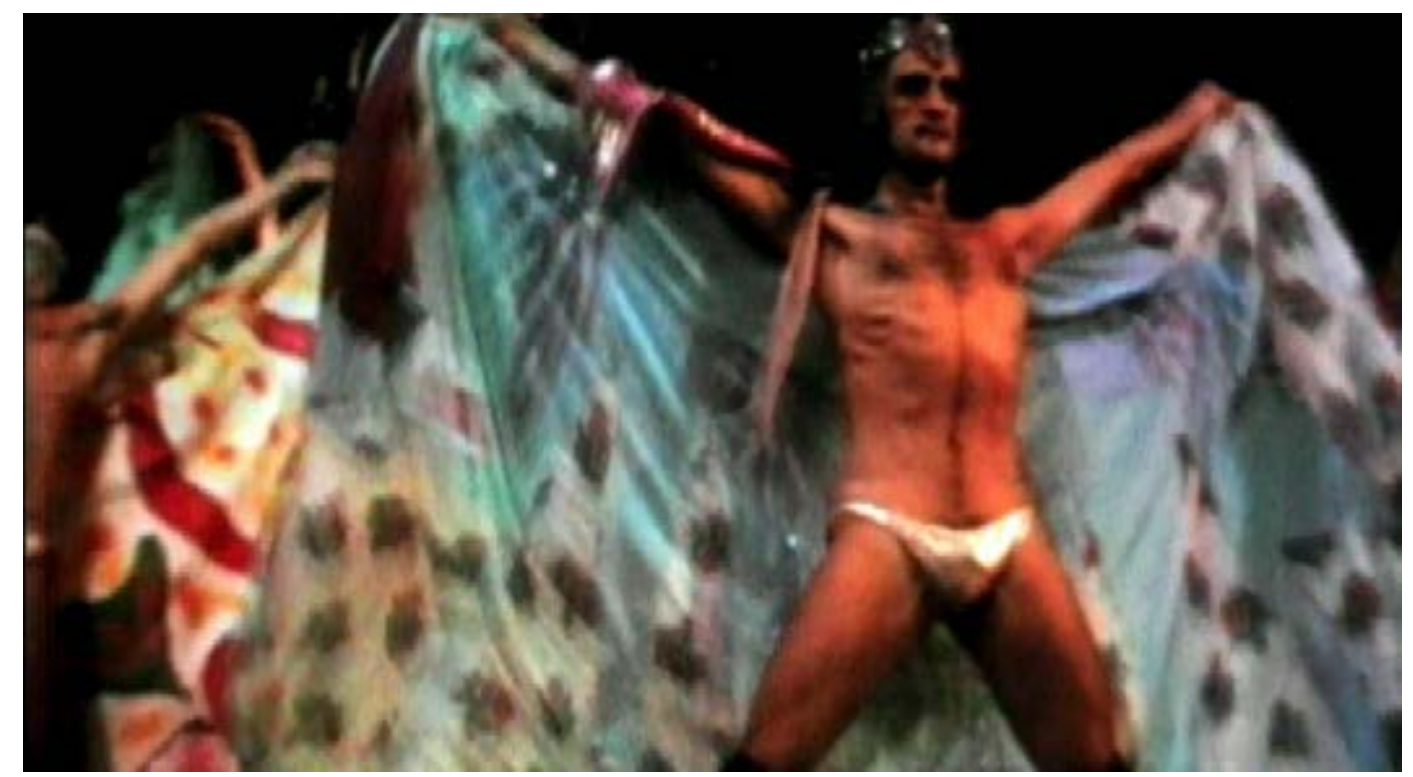

Imagem 1: Bichas espetaculosas. Fonte: Filme Dzi Croquettes (2009). Frame 0:08:34.

$\mathrm{Na}$ imagem 1, artistas do Dzi Croquettes dançam com enormes capas feitas de tecidos coloridos sob as costas, que, movidos por mãos e braços, sugerem imagens borboletas esvoaçantes. Borboletas tanto o sentido mais literal como em um sentido irônico, de borboleta como "bichina", gay espalhafatoso. Além das capas, eles usavam botas femininas de cano longo que subia acima dos joelhos, cuecas bem cavadas

3 Aparente balbúrdia, desordem, informalidade, palhaçada. 
e de tecido reluzente e arranjos brilhosos na cabeça, como coroas ou tiaras. Esta coreografia acontece ao som da música Assim falou Zaratustra de Richard Strauss. Movimentos de dança moderna e jazz são temperados com sensualidade, suavidade e força eróticas, instaurando estados de presença do corpo em cena que parecem atravessar a quarta parede palco - plateia. O movimento, olhar e a atenção dos dançarinos vão construindo e atravessando momentos de introspecção, comprometimento com a sequência coreográfica e comunicação com o público, deflagrando entrelaçamentos eróticos e semióticos nesse diálogo-dança que esse estabelece entre artistas e espectadores.

Show de intervalo e show principal, boate e teatro, profissional e albarde se (con) fundem instaurando, nos tempos sombrios da ditadura, uma proposição estética e política capaz de interpelar as imagens tradicionais de homem e mulher e provocar um sistema de governo que censurava as opiniões e atentava contra os Direitos Humanos. Em seu depoimento, no filme aqui analisado, o jornalista Darío Menezes diz que "quando proibiram o espetáculo, eles proibiram porque era um negócio tão esquisito - que eles não entendiam - que eles acharam que eram revolucionário" (Dzi Croquettes, 2009).

O estilo albarde foi agudizado quando mesclado ao profissional: ordenação, marcação e estudo dos movimentos. Os elementos da dança moderna e do jazz propostos por Dale mobilizaram um processo de preparação, estudo, planejamento e estruturação coreográfica ao espetáculo do Dzi Croquettes. Conforme Lobert (2010, p. 136), "os processos criativos e o aprimoramento da técnica", provindos da combinação do albarde e do profissional, possibilitaram a crescente qualificação do espetáculo e a efetivação da proposta inicial almejada pelos Dzi. Constituiu-se assim um modo de composição artística que, além de (per)turbar os papeis tradicionais de gênero e (mas)turbar a mentalidade rígida dos machos ditadores, causou também certa turbulência nos padrões artísticos cênicos que não alcançavam classificar que tipo de espetáculo era esse.

A conjunção dos gêneros profissional e albarde parece ter desnorteado as classificações convencionais da imprensa sobre a peça. Numa leitura do conjunto, e nas linhas e entrelinhas de anos de artigos sobre os Dzi Croquettes e em contextos diferentes, é intrigante a pequena, mas franca discussão sobre a terminologia que lhes correspondia: era "teatro", "show", "dança", "musical" ou o quê? [...] "show de categoria internacional"; "show de sátira, musicalidade, ironia e vanguardismo"; "um pouco de teatro de revista e espetáculo de circo, com happening caseiro, muito unissex nova-iorquino e um pouco de carnaval brasileiro"; "espetáculo felliniano, chapliniano e kafkiano". (Lobert, 2010, p. 137-138)

As variadas formas de opinião, classificação e adjetivação do espetáculo dos Dzi Croquettes, segundo reflete Lobert (2010, p. 138), "pareciam encobrir o incomodo" que aqueles corpos masculinos "suspeitosamente vestidos de mulher" estavam causando no contexto sócio-político-cultural. A ousadia de aparecer no palco vestindo roupas e adereços ditos femininos, performar trejeitos gays e dançar combinando sensualidade e requinte estético, implicava em sofrer as consequências disso. Trata-se de atos artísticos que eram atos de vida ao mesmo tempo. A ironia das combinações feminino e masculino, a coragem de expor-se como homem gay, a sagacidade em 
articular textos e movimentos em cenas que possibilitavam interpretações e significados que iam do universo carnavalesco brasileiro ao cinematográfico felliniano, do circo e do musical ao happening, podem ser vistos como gritos/gestos/atos/ manifestos de liberdade de corpos inseridos em um contexto político onde a vida social vinha sendo devastada pela violência, pela coerção, pela vigília, pela punição e pela morte. Modos performativos de romper com discursos e regimes ditatoriais instaurando modos alternativos de ser.

\section{Performatividade: modos de realizar o que se nomeia}

Butler (2012) reflete sobre os limites materiais e discursivos do sexo e argumenta sobre como os discursos tradicionais sobre sexo e gênero formam-nos enquanto corpos; os modos como vamos repetindo, performativamente, esses discursos os reiteram e dão-lhes legitimidade; assim, os discursos e a sua repetição performativa formam/materializam nossa sexualidade e nossa identidade de gênero. Butler (2012, p. 18) interpela as compreensões de que a natureza nos dá o sexo biológico e a cultura inscreve em nós o gênero argumentando que não há como "interpretar el 'género' como una construcción cultural que se impone sobre la superficie de la matéria, entendida o bien como 'el cuerpo' o bien como su sexo dado".

[...] la performatividad debe entenderse, no como un "acto" singular y deliberado, sino, antes bien, como la práctica reiterativa y referencial mediante la cual el discurso produce los efectos que nombra. [...] las normas reguladoras del "sexo" obran de una manera performativa para constituir la materialidad de los cuerpos y, más específicamente, para materializar el sexo del cuerpo, para materializar la diferencia sexual en aras de consolidar el imperativo heterosexual. (Butler, 2012, p. 18)

Performatividade é um complexo conjunto de ações, de práticas reiterativas, mediante as quais discursos, leis e normas realizam/concretizam/materializam/corporificam aquilo que nomeiam. Trata-se de uma complexa rede de relações de poder que envolvem natureza e cultura ao mesmo tempo - não apenas entre pessoas, mas que envolvem essas, as leis, os discursos, as condições dos ambientes/contextos, tempo e espaço. Nesse sentido, a materialidade que constitui o caráter fixo do corpo, seus contornos e movimentos é um dos efeitos produtivos dessas complexas relações de poder. Na articulação entre poder e saber relacionada à sexualidade, a compreensão de poder torna-se fundamental. Assim, "o poder" configura-se como "uma multiplicidade de relações de força, um jogo de lutas e afrontamentos, é uma situação estratégica complexa numa sociedade determinada" (Foucault, 1988, p.89).

É no discurso, ou seja, na multiplicidade de elementos discursivos que poder e saber se articulam. A sexualidade, desta forma, constitui-se num ponto de passagem, denso, pelas correlações de força: desequilibradas, instáveis, tensas. A resistência é constitutiva do poder e, logo, não há poder sem resistência. A materialidade do corpo é concebida mediante a materialidade das normas reguladoras. Para Butler (2012, p. 19) o sexo não é algo que alguém tem ou uma descrição estática do que alguém é, mas "una de las normas" mediante as quais esse alguém pode chegar a ser viável, uma "norma que califica un cuerpo para toda la vida dentro da esfera de la inteligibi- 
lidad cultural". Quando uma criança nasce e o médico proclama: "é menino!" ou "é menina!", esse discurso realiza aquilo que nomeia, pois deflagra aos que presenciam o nascimento e, portanto, ao recém-nascido/a, os modos de ser homem ou mulher a serem seguidos, as práticas reiterativas (confirmatórias) dos discursos normativos tradicionais de sexo e gênero.

O sexo não é uma realidade fixa do corpo, como o próprio corpo não é fixo. $O$ sexo é um ideal regulador que vai sendo construído e se materializando ao longo do tempo. Conforme afirma enfaticamente Butler (2012, p. 18), sexo é "una construcción ideal [...] un processo mediante el qual las normas reguladoras materializam el 'sexo' y logran tal materialización em virtude de la reiteración forzada de esas normas". Ao forçar a necessidade de sua reiteração (repetição, confirmação) para que sejam efetivadas, as normas e discursos também deflagram sua instabilidade e fraqueza. Para ter vida, a norma necessita dos corpos que regula, ela depende de que eles a validem, a reiterem, a coloquem em prática. Para Butler (2012, p. 28) "no hay ningún poder que actúe, sólo hay una actuación reiterada que se hace poder en virtude de su persistencia e instabilidad". Nesta linha de pensamento compartilhamos das reflexões de Richard Miskolci sobre a construção e o desenvolvimento de novas formas de relacionamento que podem resultar em uma maior liberdade em relação às pressões e aos constrangimentos exercidos pelos efeitos do poder.

A prova das alternativas disponibilizadas pelo trabalho de crítica do presente atende pelo nome de estética da existência. Foi justamente ela que marcou as últimas reflexões do filósofo francês. Entre fins da década de setenta e início dos anos oitenta, a descoberta das comunidades gays norte-americanas e a reestruturação do projeto dos últimos volumes da História da Sexualidade levaram Foucault a refletir sobre as possibilidades de transformação social abertas pelos novos estilos de vida criados pelos gays. (Miskolci, 2008, p.228).

A norma é investida de poder através do complexo conjunto de práticas que a reiteram, que a confirmam. Normas e corpos se (con)fundem, materializando-se, conformando-se e confirmando-se uns aos outros. Os processos de normalização e moralização característicos do poder disciplinar englobam os elementos da disciplina, da vigilância e do exame. Ao descrever a dinâmica de exercício do biopoder Foucault também apontou suas possibilidades de resistência, de contestação e transgressão à(s) norma(s).

\section{Corpos que excedem as normas}

Butler (2012) vê possibilidades de repetição das normas de modo excessivo, a ponto de excedê-las, nas formas de atuação das drag queens da ball culture apresentadas no filme Paris is Burning. Trata-se de corpos que repetiam as normas de gênero, as imagens heteronormativas de homem e de mulher, em suas montagens, vestimentas, desfiles e shows a ponto de explicitar o quanto esses papéis de gênero são repetições idealizadas que vão se materializando nos corpos, são informações/ imagens que os corpos assumem e tornam corpo. Assim o faziam os corpos da ball culture, tanto nos shows quanto em seu cotidiano, em seus modos de reformulação 
do parentesco. Eles extravasam as noções de gênero, raça e parentesco ao reunirem-se e se fazerem pertencentes às "casas" - clubes/boates que expandiam seus significados ao agruparem homens e mulheres (gays, lésbicas, brancos, negros, latinos) nas festas/desfiles e estendendo-se para uma convivência cotidiana de familiaridade. Cada casa tinha uma "mãe" (um homem - drag queen) que cuidava e se preocupava com os "filhos", por vezes providenciando teto, comida e demais cuidados.

Para Butler (2012, p. 337), esses corpos possibilitam vias de "redefinición de la 'casa' y sus formas de colectividad [...], la apropriación y el redespliegue de las categorias dominantes" permitindo a criação de "relaciones de parentesco que, al oferecer apoyo incondicional, funcionen como discursos opositores" às normas de gênero reguladoras. Por esse viés também buscamos compreender os modos como os corpos do grupo Dzi Croquettes organizavam formas de coletividade, vivendo juntos na mesma casa e também criando formas de atuação reiterativa da noção de família (na cena e na vida cotidiana) através das quais estabeleciam e distribuíam entre si os papéis do "pai", da "mãe", das "filhas", da "empregada", da "tia".

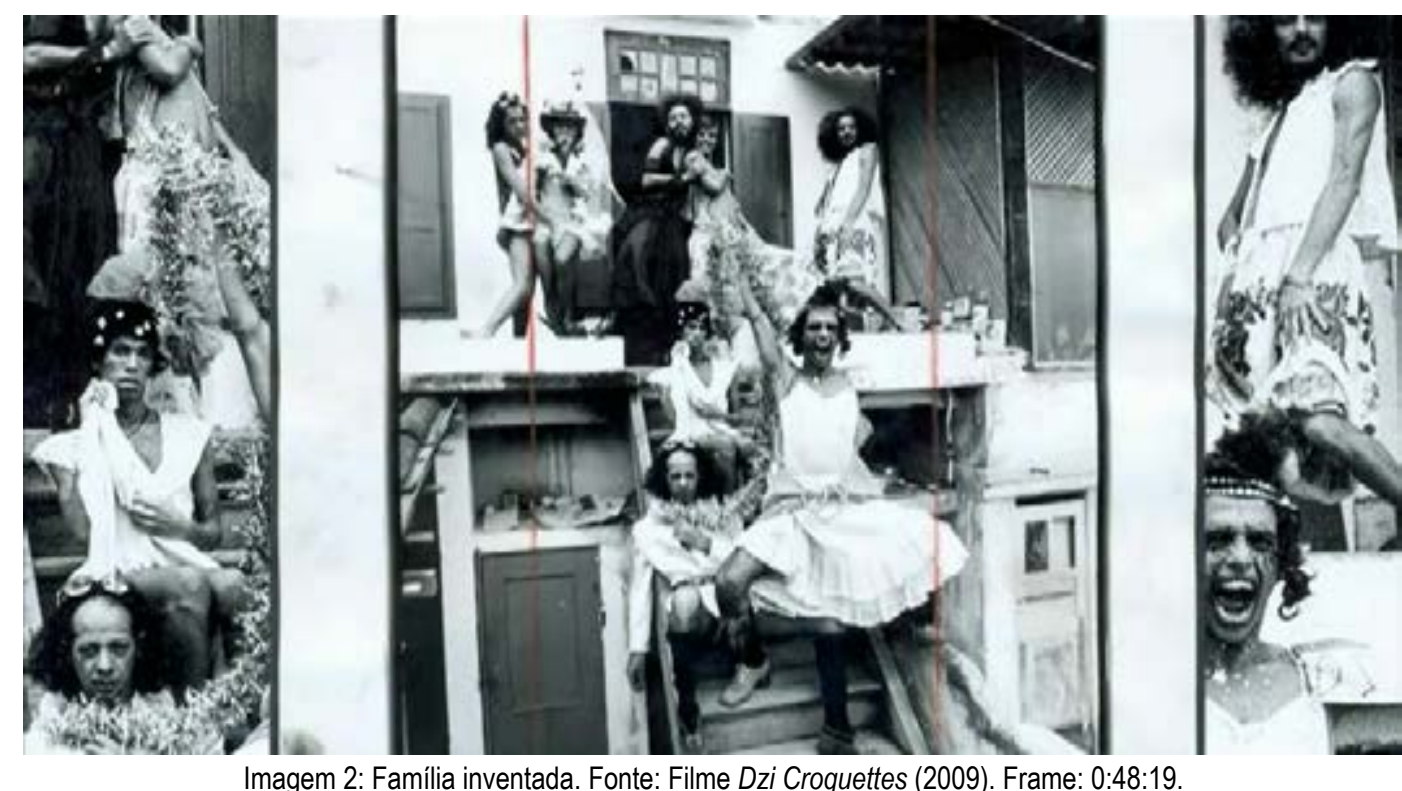

$\mathrm{Na}$ Imagem 2, os integrantes do Dzi Croquettes aparecem num momento bastante descontraído no cotidiano de sua vida em comunidade. A vida em conjunto na mesma casa engendrava formas diferentes de ser família. As poses mais engraçadas de uns e mais sérias de outros, fazem lembrar de antigos retratos de família onde as figuras da família são bem demarcadas e posicionadas. Nessa imagem da família Dzi Croquettes os tradicionais papéis de gênero são nebulosos, não identificáveis, borrados pela ironia das vestimentas femininas em corpos masculinos, pelo gracejo das poses e trejeitos. Os modos audaciosos como usavam os termos tradicionais para se referir aos graus de parentesco, nomeando "o pai", "a mãe", "as filhas", e outros, na vida em grupo, dentro da mesma casa, possibilitam refletir sobre a performatividade que materializa esses discursos tradicionais nos corpos; as formas de ressignificação dos discursos tradicionais de família; e os atos performativos que podem realizar essas ressignificações. 
Nesta perspectiva, Francisco Ortega, ao estudar a obra de Michel Foucault, se propõe a aprofundar a dimensão agonística ${ }^{4}$ intersubjetiva do cuidado de si relacionando-a com a análise da amizade onde esta é compreendida como

[...] um convite, um apelo à experimentação de novos estilos de vida e comunidade. Reabilitá-la representa introduzir movimento e fantasia nas rígidas relações sociais, estabelecer uma tentativa de pensar e repensar as formas de relacionamento existentes em nossa sociedade, as quais, como observa Foucault, são extremamente limitadas e simplificadas. (Ortega, 1999, p. 26)

Com Butler (2012, p. 338) refletimos sobre as formas de vida e arte do grupo Dzi Croquettes na busca de compreender como as categorias "casa", "pai", "mãe", "filhas", "empregada", "tia" derivam das normativas familiares tradicionais, mas são deslocadas, repetidas de modo excedente, escandaloso para muitos, formando "hogares y comunidades alternativos". Prosseguindo com Butler (2012, p. 338), "esta resignificación" dos termos/discursos/normas sinaliza os efeitos de "una capacidad de acción" desses corpos que, ainda que esteja "implicada en las mismas relaciones de poder con las que procura rivalizar", não se reduz a essas formas dominantes de família, parentesco e coletividade.

Para muitos, falar/nomear "família" é declarar/realizar o modelo heteronormativo de pai, mãe e filhos, cada um com funções modelares também já prescritas nessa norma/termo a serem praticadas. Todavia, os corpos da ball culture e do Dzi Croquettes possibilitam percebermos formas alternativas, atos performativos, de ressignificação desses termos. Da mesma maneira, Butler (2012) reflete sobre o termo inglês queer que em sua acepção original é um termo pejorativo que significa esquisito, estranho, afeminado. Também os termos "bicha", "viado", "homossexual", "gay", em seu uso tradicional mais corrente, designam xingamentos, modos depreciativos de se referir a determinados sujeitos, em tom de humilhação. Estes termos/discursos operam no sentido de realizar aquilo que nomeiam, ou seja, estabelecer e materializar nos corpos (fazer com os corpos tornem corpo), a norma de que "gay", "viado", "bicha" - os corpos queers - são degenerados, anômalos, anormais, desviados das normas/ termos/discursos que materializam nos corpos (fazem os corpos tornar corpo) o que é "família", "pai", "mãe", "homem", "mulher".

Conforme destaca Butler (2012), o uso contemporâneo do termo queer tem deslocado suas significações somente ligadas à degradação e à negação de sujeitos, excedendo-as e sinalizando significações afirmativas e políticas de representação. Com isso, é possível percebermos o como a força performativa dos termos - de realizar aquilo que nomeiam - pode sofrer reapropriações, passando por cadeias contínuas de interpretações e adaptações. Hoje o uso performativo do termo queer pode ser visto como um emblema de autonomia e empoderamento dos sujeitos LGBTT. O termo queer, que para muitos ainda designa negação de sujeitos, em seu uso performativo contemporâneo designa a afirmação de sujeitos que, ao realizarem essa repetição reiterativa de um termo normativo, aproveitam a debilidade e a instabilidade dessa norma para, de modo subversivo, colocar o poder contra ele mesmo,

4 Relações agonísticas são relações livres que apontam para o desafio e para a incitação recíproca e não para a submissão ao outro (Ortega, 1999, p.168). 
usar a norma contra ela mesma. Isso manifesta, conforme Butler (2012, p. 333), que "la resignificación de las normas es pues una función de su ineficácia".

Ao terem seu trabalho identificado como "show de travestis", os Dzi Croquettes sofreram as consequências tanto do peso pejorativo do termo "travesti", atraindo a censura de um regime ditador (que, entre outras cosias, primava pelas normas da família e da disciplina tradicionais), como do sentido afirmativo do termo que atraiu público e um séquito de seguidores - "as/os tietes". Estes/as que, além de frequentar os espetáculos, passaram a uma postura de identificação com a proposta política e estética do grupo, vestindo-se, comportando-se e vivendo de acordo com o estilo Dzi Croquettes. A sagacidade dos Dzi Croquettes em instaurar uma proposta política-estética que, vazando da cena para a vida ou da vida para a cena, causava rearticulações e (des)identificações de/com termos/normas/categorias tradicionais como "família", "sexo", "arte", nos impele a interpretar isso como atos peformativos que materializam aquilo que (re)nomeiam. Nesse sentido, nos propomos a pensar sobre como esses atos performativos podem interpelar o ensino de dança na contemporaneidade.

Junto das proposições de Butler (2012, p. 21), esses corpos masculinos vestidos de mulher - viados ou travestis -, que emergiram nos palcos apertados de boates e passaram a ocupar os largos palcos de teatros brasileiros e europeus, deflagram possibilidades para pensarmos sobre uma política queer a ser mobilizada através de "prácticas que destacan la desidentificación com aquellas normas reguladoras" que objetivam materializar, por exemplo, a diferença sexual. Acreditamos que diferentes formas de desidentificações coletivas podem instaurar novas compreensões sobre: quais são os corpos que importam? Por que uns importam mais que outros? Quem ou que normas definem quem importa mais e quem importa menos? Que corpos já existem e que outros haverão de emergir como matéria crítica de importância e interesse político, de gênero, educacional e artístico? Como o ensino contemporâneo de dança pode propor caminhos para isso?

\section{Dramaturgias e pedagogias ao estilo Dzi Croquettes}

O atual momento de instabilidade política e crise econômica que vive o Brasil, sob a ameaça de um novo golpe militar, leva-nos a questionar o sentido que tem ensinar e fazer dança hoje. O que pode a dança inserida neste cenário sócio-político-cultural? Quais ações a dança pode provocar no sentido de intervir nesse contexto? Quais dramaturgias podem emergir das interações dos corpos com o mundo? Quais procedimentos dramatúrgicos podem ser acionados e (re)criados para organizar elementos vindos da interação corpo-mundo em forma de dança? Quais caminhos são possíveis para nos desvencilharmos das dramaturgias da representação cênica clássica e articular outras dramaturgias na dança?

Entrecruzando os estudos de Setenta (2008) sobre dança e performatividade e os desdobramentos que Butler (2012) faz do conceito de performatividade identificando-a com a materialidade do corpo que buscamos compreender a dança do grupo Dzi Croquettes. A compreensão de dança que articulamos se distancia dos padrões clássicos de representação cênica ou de mera repetição de passos predeterminados e se aproxima de formas de dança na qual as ações/movimentos/gestos são criadas em 
relação às experiências de vida dos corpos que dançam. Com isso estamos propondo que os passos/movimentos de dança não funcionem apenas como suportes materiais/físicos para transmitir uma mensagem/ideia/tema externa/alheia aos corpos que dançam. A constituição da dança no corpo resulta das interações desse corpo com o mundo, de seus vínculos com a sociedade e as estruturas de poder.

As proposições de vida e arte do grupo Dzi Croquettes ascendem sagazes questões sobre como os gêneros 'profissional' e 'albarde' podem interpelar as dramaturgias do corpo que operam na organização cênica da dança. A interconexão profissional e albarde - que leva para os teatros a picardia das boates - podem nos fazer rever compreensões artísticas puristas ainda calcadas na representação cênica clássica, mais afeita aos elementos cênicos (cenário, figurino, música etc.) que os corpos propriamente ditos. Os gêneros 'profissional' e 'albarde' proporcionam pensar uma dramaturgia na dança que desnuda o corpo dos artifícios cênicos, proporcionando que este deixe de estar à mercê dos pesos da dramaturgia cênica clássica ou de uma dramaturgia institucional (Hércoles, 2014) para expandir movimento, técnica e expressividade.

Nessa perspectiva, nos perguntamos sobre a viabilidade de pensar-fazer na dança formas de dramaturgia capazes de ressignificar os termos, compreensões e elementos cênicos tradicionais no sentido de organizá-los em função da necessidade do corpo que dança e não à revelia ou sobrepostos a este. Formas de dramaturgia onde a pura representação de algo externo ao corpo que dança - que faz do movimento um mero mecanismo de transmissão - perde seu sentido em face à sagacidade artística que as interações desse corpo o mundo pode proporcionar à cena. Uma dramaturgia que organiza estratégias para o corpo interagir com os elementos que compõem a cena, sem hierarquias e apagamentos, proporcionando ao corpo manifestar-se sem máscaras ou acobertamentos. Figurino, maquiagem, cenografia, música, são, assim, como que extensões do corpo, elementos que, com ele, constituem o fluxo - dança.

Neste sentido, buscamos pensar sobre como o ensino de dança nas universidades, em meio a tantas relações de saber e poder pode proporcionar aos futuros bacharéis e licenciados a construção de compreensões de dança baseadas nos princípios foucaultianos de liberdade, vida criativa e inventiva e transformação de si próprio. A influência do pensamento de Michel Foucault se direciona no sentido da compreensão do conceito de liberdade - de uma liberdade possível - baseada em uma vida criativa e inventiva, isto é, pensar com e a partir do "último Foucault" da genealogia da ética, do cuidado, das técnicas e tecnologias de si. Ou seja, o processo de transformação das investigações de Foucault se aproxima das invenções e inquietações vivenciadas, na vida e na dança, pelos integrantes do Dzi Croquettes onde

[...] as práticas pelas quais os indivíduos por seus próprios meios ou com a ajuda de outros, agem sobre seus próprios corpos, almas, pensamentos, condutas e formas de ser, de forma a transformar-se a si próprios e chegar a certo estágio de perfeição ou felicidade, ou tornar-se sábio ou imortal, chegar a virtude. Este novo projeto se constitui numa genealogia de como o si se constitui a si mesmo como sujeito. (Eizirik, 1995, p.46)

Nessa perspectiva, compreendemos que a dança sensual, homoerótica, irônica, carnavalesca e cabarezeira dos Dzi Croquettes não era uma representação alheia às suas vidas cotidianas e ao seu contexto sócio-político-cultural, mas um discurso corporal 
- forma de posicionamento emergido das suas formas de ser, viver e interagir com a sociedade da época e suas estruturas de poder. Isso nos interpela a pensar em estratégias e procedimentos de ensino e criação de dança onde seja possível estimular os alunos a fazer-pensar dança atentos às suas interações com o mundo. Perante uma tradição que nos ensinou a dançar músicas, a criar ou repetir passos vinculados à marcação da métrica musical e, ainda, a contar diferentes contos fantasiosos através dos mesmos passos de dança, torna-se um desafio propor processos criativos e pedagógicos de dança onde os movimentos não sejam apenas reflexos de uma música ou mecanismos de transmissão de mensagens/temas/ideias alheios aos corpos que dançam. É desafiador e motivador pensar e propor formas de dançar nas quais os corpos se empoderem a aprender, compreender e fazer (sua) dança como ato performativo, como arte não desconecta da vida, como ação que realiza aquilo a que se refere sem recorrer a artifícios alheios ao seu processo criativo e vivencial.

Pensar processos e dramaturgias de dança imbricados com a compreensão de performatividade é provocar fricções e turbulências em procedimentos pedagógicos há tempos acostumados com transmissão bancária de conhecimentos. Compreendemos que ao pensar o ensino de dança relacionado à performatividade é pensar o próprio processo de ensino como performativo. Ou seja, é pensar e interpelar os modelos pedagógicos que têm buscado materializar nos corpos discursos e teorias, muitas vezes, alheios e até depreciativos das suas experiências, usando da disciplina, do rigor, da vigília e da punição para alcançar tal intento. Pedagogias a serviço de discursos e normas reguladoras, mecanismos arbitrários afeitos a persuadir os corpos a tornarem corpo - materializarem - papéis de gênero, conteúdos, normas sexuais, formas de comportamento social etc.

Olhar para as ações artísticas do grupo Dzi Croquettes, suas formas alternativas de articulação de parentesco e coletividade, seus modos de posicionar-se perante a censura do regime militar, seu entrecruzamento dos elementos albarde e profissional em correlação com processos (de ensino e criação) e dramaturgias de dança, pode ser visto como afronta. Como uma forma de desrespeito e degradação da tradicional missão da educação de culturalizar/civilizar os corpos e que os vê como tábulas rasas, máquinas ou recipientes a serem preenchidos de conteúdos e valores e treinados para a vida em sociedade.

Questionando os atrelamentos da pedagogia com a produção do discurso e como isso constitui o processo formativo dos corpos, Giroux (1999, p. 226) argumenta que

[...] a pedagogia também constitui um momento em que o corpo aprende, se movimenta, deseja e anseia por afirmação. Essas indagações também sugerem uma rejeição da pedagogia da modernidade, uma pedagogia que serve a formas "ideais" da teoria da comunicação, em que a tirania do discurso torna-se o meio pedagógico fundamental, ou seja, a conversa incorporada abstraída do próprio corpo.

Giroux (1999, p. 226) evidencia a necessidade de abrir a pedagogia para o incerto, ou seja, fazer-pensar uma pedagogia que recusa a hegemonia do mensurável e valoriza o concreto de uma maneira que é "mais sentida e experimentada do que meramente falada". Refletindo com Giroux, investimos numa perspectiva de ensino que não apenas 
inverte as polaridades, privilegiando o corpo sobre o discurso, mas questiona como o corpo tem sido ausentado das teorizações prévias e evidencia a importância do corpo para uma pedagogia crítica. Pensar o ensino de dança nessa perspectiva performativa nos leva a perceber que não é possível ensinar a dança, se compreendermos que ensinar é sinônimo de transmitir, apenas. Na perspectiva da performatividade, a dança não é apenas uma coreografia que o corpo-professor transmite para o corpo-aluno ou o corpo-coreógrafo transmite para o corpo-dançarino. Trata-se de um modo de fazer-pensar dança voltado para as experiências dos corpos com o mundo, para seus modos de sociabilidade. Esta intensificação da relação consigo pela qual o sujeito se constituía enquanto sujeito de seus atos configurou o "[...] desenvolvimento daquilo que se poderia chamar uma "cultura de si", na qual foram intensificadas e valorizadas as relações de si para consigo" (Foucault, 1985, p.49).

Pensar o ensino contemporâneo de dança a partir de questionamentos advindos do trabalho artístico do grupo Dzi Croquettes e da compreensão da performatividade, pode abrir sulcos no grande e ainda novo terreno da formação em dança nas universidades. Investimos, portanto, em possibilidades de construção de vias alternativas capazes de questionar e ressignificar relações de poder e saber na dança, dando vez ao corpo e suas múltiplas formas de ser, às suas variadas experiências construídas na interação com o mundo. Investimos em processos e dramaturgias de dança que enfatizam a relação do sujeito consigo e esta sempre imersa na alteridade, ou seja, conectada ao outro. Olhar para a vida e obra do grupo Dzi Croquettes em conexão com o ensino universitário de dança na contemporaneidade é interpelar relações opressoras de saber e poder, de questionar os saberes bancários que apenas transmitem passos e de desconstruir as dramaturgias que pesam sobre os corpos, articulando assim, espaços pedagógicos e artísticos onde o entrecruzamento profissional - albarde possibilitem aos corpos ousadias para ser e se mover, na dança e na vida.

\section{Referências}

BERTÉ, O. Dança Contempop: corpos, afetos e imagens (mo)vendo-se. Santa Maria: Ed. da UFSM, 2015.

BUTLER, J. Cuerpos que importan: sobre los límites materiales y discursivos del sexo. $2^{a}$ ed. Buenos Aires: Paidós, 2012.

DZI Croquettes. Direção de Tatiana Issa e Raphael Alvarez. Rio de Janeiro: TRIA Productions. Imovision DVD, Cinema e Arte Distribuidora, 2009. 1 DVD (110 min.): DVD, NTSC, color.

EIZIRIK, MARIA F. Michel Foucault: sobre a passagem do poder/saber à genenalogia da ética. In.: Cadernos de Sociologia - Programa de Pos-graduação em Sociologia, v.7, Porto Alegre: UFRGS, 1995.

FOUCAULT, Michel. História da Sexualidade I: a vontade de saber. Rio de Janeiro, Edições Graal, 1988. 
FOUCAULT, Michel. História da Sexualidade III: o cuidado de si. Rio de Janeiro, Edições Graal, 1985.

GIROUX, H. Cruzando fronteiras do discurso: novas políticas em educação. Artmed: Porto Alegre, 1999.

HÉRCOLES, R. O corpo da dramaturgia de dança. In: PATERNOSTRO, C. (Org.). Seminário Conexão Dança Alemanha-Bahia. Salvador: EDUFBA, 2014.

LOBERT, R. A palavra mágica: a vida cotidiana do Dzi Croquettes. Campinas: Ed. da UNICAMP, 2010.

MISKOLCl, Richard. Estética da existência e pânico moral. In.: Figuras de Foucault Margareth Rago e Alfredo Veiga-Neto (orgs.) Belo Horizonte: Autêntica, 2008.

MULLER, R. P.; Apresentação. In: LOBERT, R. A palavra mágica: a vida cotidiana do Dzi Croquettes. Campinas: Ed. da UNICAMP, 2010.

ORTEGA. Francisco. Amizade e Estética da Existência em Foucault. Graal Editora, 1999.

PARIS is burning. Produção e direção de Jennie Livingston. New York: Academy Entertainment Off White Porductions. Miramax Films Distribuidora, 1990. 1 DVD (76 min.): DVD, NTSC, color.

SETENTA, J. S. O fazer-dizer do corpo: dança e performatividade. Salvador: EDUFBA, 2008.

SIMÕES, Julio A. \& FACCHINI, Regina. Do movimento homossexual ao LGBT. São Paulo: Editora Fund. Perseu Abramo, 2009.

TREVISAN, João Silvério. Devassos no paraíso: a homossexualidade no Brasil: da colônia à atualidade. Edição revista e ampliada. 6 ed. Rio de Janeiro: Record, 2004.

PARKER, Richard. Abaixo do Equador. Tradução de Ryta Vinagre. Rio de Janeiro: Record, 2002.

POCAHY, Fernando Altair. Entre Vapores e Dublagens: dissidências homo/eróticas nas tramas do envelhecimento (Tese de Doutorado). Programa de Pós-Graduação em Educação - UFRGS, Porto Alegre/RS, 2011.

VOGUE. Madonna Videoclipe. Direção de David Fincher. Estados Unidos da América, 1990. (4'53"). P/B.

Recebido em: 03/03/2018

Aprovado em: 06/05/2018 